\title{
Herpes Zoster pada Anak - Laporan Kasus
}

\author{
${ }^{1}$ Thigita A. Pandaleke, ${ }^{1}$ Herry E. J. Pandaleke, ${ }^{2}$ Ratna I. Susanti, ${ }^{2}$ Julieta D. P. \\ Dotulong
}

\author{
${ }^{1}$ Bagian/KSM Ilmu Kesehatan Kulit dan Kelamin Fakultas Kedokteran Universitas Sam \\ Ratulangi/RSUP. Prof. Dr. R. D. Kandou Manado \\ ${ }^{2}$ PPDS Ilmu Kesehatan Kulit dan Kelamin Fakultas Kedokteran Universitas Sam Ratulangi \\ Manado \\ Email: th_pandaleke@yahoo.com
}

\begin{abstract}
Herpes zoster (HZ) is an acute vesicular eruption caused by latent varicella zoster virus (VVZ) reactivation in sensory ganglia after primary infection. Its incidence increases with age and it is rarely found in children. We reported a case of 10-year-old male with blisters on the right side of his stomach and back 3 days ago. The patient was suffered from fever, common cold, and cough a week before, and had a history of varicella at 5 years old. Dermatologic status showed multiple vesicles on erythematous base at the anterior dan posterior sides of his right lumbar region. The Tzank test showed multinucletaed giant cells. Acyclovir resulted in significant improvement after 7- day therapy. Conclusion: Diagnosis of herpes zoster was based on anamnesis, physical examination, and laboratory findings. Antiviral drugs was aimed to reduce complications and viral shedding.
\end{abstract}

Keywords: Herpes zoster, child

\begin{abstract}
Abstrak: Herpes zoster (HZ) merupakan erupsi vesikuler akut yang disebabkan oleh reaktivasi dari virus varisela zoster (VVZ) laten pada ganglia sensoris yang sebelumnya terpajan dengan infeksi primer varisela. Insiden $\mathrm{HZ}$ meningkat seiring pertambahan usia dan jarang ditemukan pada anak-anak. Kami melaporkan kasus seorang anak laki-laki, 10 tahun, dengan bintil-bintil berair di perut dan punggung sebelah kanan sejak 3 hari lalu. Riwayat demam, batuk dan pilek 1 minggu sebelum timbul lesi. Riwayat varisela pada usia 5 tahun. Status dermatologis ditemukan vesikel multipel berisi cairan jernih yang tersusun bergerombol di atas kulit yang eritema di regio lumbar dekstra anterior dan posterior. Tes Tzank memperlihatkan sel raksasa berinti banyak. Pasien diterapi dengan asiklovir oral selama 7 hari dan menunjukkan perbaikan yang bermakna. Simpulan: Anamnesis, pemeriksaan fisik, dan pemeriksaan penunjang kasus ini khas untuk herpes zoster. Pemberian obat antiviral bertujuan untuk mengurangi komplikasi dan menurunkan viral shedding.
\end{abstract}

Kata kunci: herpes zoster, anak

Herpes zoster merupakan erupsi vesikuler akut yang disebabkan oleh reaktivasi dari virus varisela zoster (VVZ) laten pada ganglia sensoris setelah sebelumnya terpajan dengan infeksi primer varisela. ${ }^{1}$

Prevalensi herpes zoster tidak dipengaruhi oleh ras, jenis kelamin, atau musim. Insiden penyakit ini meningkat sejalan dengan pertambahan usia dan jarang ditemukan pada anak-anak. ${ }^{2,3}$ Herpes zoster dapat terjadi pada anak yang memiliki riwayat infeksi primer intrauterin, kondisi imunokompromais, dan yang terinfeksi varisela pada tahun pertama kehidupannya. ${ }^{2,4,5}$

Patogenesis herpes zoster belum sepenuhnya diketahui dengan pasti baik pada anak maupun orang dewasa, tetapi biasanya dihubungkan dengan keadaan imunosupresi, stres emosional, penyinaran, 
tumor pada spinal, trauma, serta operasi pada daerah spinal dan sinusitis oftalmik. ${ }^{2,3}$

Gejala klinis herpes zoster secara umum diawali oleh gejala prodromal yang dapat terjadi 1-3 minggu sebelum lesi kulit timbul, berupa nyeri radikuler, parestesia, malaise, nyeri kepala, dan demam. ${ }^{6}$ Pada anak-anak, gejala prodromal jarang terjadi. ${ }^{3}$ Erupsi kulit biasanya unilateral, namun dapat mengenai 1-3 dermatom. Terdapat vesikel berkelompok di atas dasar eritematosus yang kemudian pecah/mengering menjadi krusta dan sembuh dalam 1-3 minggu. Selama 1 minggu pertama vesikel baru masih dapat timbul. Sebagian besar sembuh tanpa parut, kecuali bila terjadi infeksi sekunder bakterial. Lesi kulit yang terjadi pada anak lebih ringan dan durasinya lebih pendek. ${ }^{7.8}$

Pemeriksaan penunjang pada herpes zoster berupa tes Tzank, biopsi kulit, kultur virus, fluorescent antibody, uji serologis, dan polymerase chain reaction (PCR). ${ }^{1-3}$

Herpes zoster pada anak imunokompeten dapat sembuh dengan sendirinya sehingga penatalaksanaan yang diberikan hanya bersifat suportif, akan tetapi pemberian terapi spesifik dapat dipertimbangkan pada kasus-kasus tertentu. ${ }^{8,9}$

Berikut ini dilaporkan satu kasus herpes zoster torakolumbal pada seorang anak berusia 10 tahun.

\section{LAPORAN KASUS}

Seorang anak laki-laki berusia 10 tahun datang ke Poliklinik Kulit dan Kelamin RSUP Prof. Dr. R. D. Kandou Manado dengan keluhan bintil-bintil berair di daerah perut dan punggung sebelah kanan yang timbul sejak 3 hari lalu. Awalnya pasien mengeluh nyeri di daerah perut dan punggung sebelah kanan. Selanjutnya, dua hari kemudian timbul bintil-bintil merah berair dan berkelompok di perut kanan menjalar ke punggung sebelah kanan. Pasien belum pernah berobat ke dokter untuk keluhan ini. Sekitar satu minggu sebelumnya, pasien mengeluh batuk dan pilek yang disertai demam, namun keluhan ini membaik setelah minum obat batuk dan penurun panas.
Pada pemeriksaan fisik ditemukan keadaaan umum baik, tanda-tanda vital dalam batas normal, tinggi $137 \mathrm{~cm}$ dan berat badan $29 \mathrm{~kg}$, dengan indeks massa tubuh normal. Pada status dermatologis ditemukan lesi pada regio lumbar dekstra anterior dan posterior berupa vesikel multipel bergerombol di atas dasar makula eritematosa berisi cairan jernih (Gambar 1). Tes Tzank memperlihatkan adanya sel raksasa berinti banyak.

Penatalaksanaan meliputi nonmedikamentosa dengan memberikan informasi dan edukasi mengenai penyakit dan faktorfaktor pencetus serta menjelaskan tentang pengobatan yang diberikan. Medikamentosa diberikan asiklovir tablet 4x225 mg selama 7 hari, parasetamol tab 3x375mg dan bedak salisil ditabur pada lepuh yang belum pecah. Follow up pasien satu minggu setelah terapi yaitu pada hari ke-14 (Gambar 2) menunjukkan perbaikan yang optimal.

\section{BAHASAN}

Herpes zoster merupakan reaktivasi dari virus varisela zoster (VVZ) laten pada ganglia sensoris setelah terpajan dengan infeksi primer varisela. Berdasarkan acuan pustaka, herpes zoster pada individu imunokompeten terjadi karena reaktivasi VZV itu sendiri yang seringkali dipicu oleh demam, stres, terapi radiasi, atau trauma. ${ }^{7}$ Pasien ini pernah mengalami varisela pada usia 5 tahun, terdapat riwayat demam, batuk, pilek, dan memiliki aktivitas fisik sering bermain bola.

Berdasarkan autoanamnesis didapatkan keluhan adanya bintil-bintil merah berair di daerah perut dan punggung sebelah kanan yang timbul sejak 3 hari sebelum pasien datang ke rumah sakit. Awalnya pasien mengeluh nyeri perut dan punggung sebelah kanan, kemudian timbul bintil-bintil merah berair dan berkelompok di daerah perut kanan yang menjalar ke punggung sebelah kanan. Riwayat batuk dan pilek dan demam dialami 1 minggu sebelum timbul lesi, namun keluhan membaik setelah minum obat batuk dan penurun panas. 

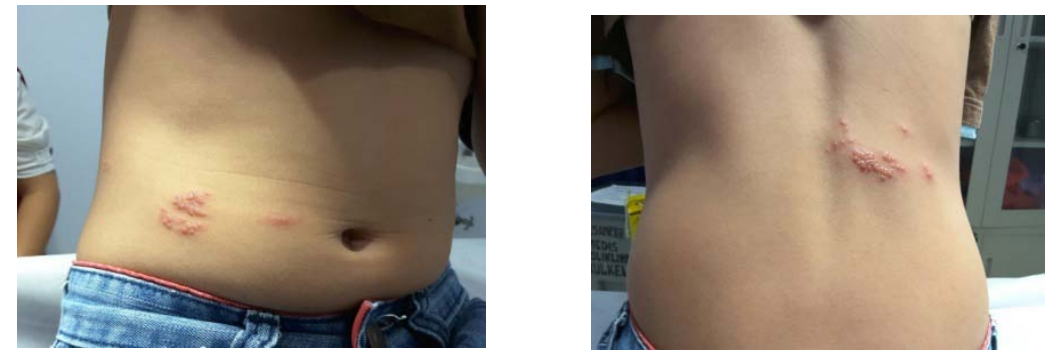

Gambar 1. Hari ke-1 tampak vesikel bergerombol multipel diatas dasar eritematosa, berisi cairan jernih di perut dan punggung sebelah kanan
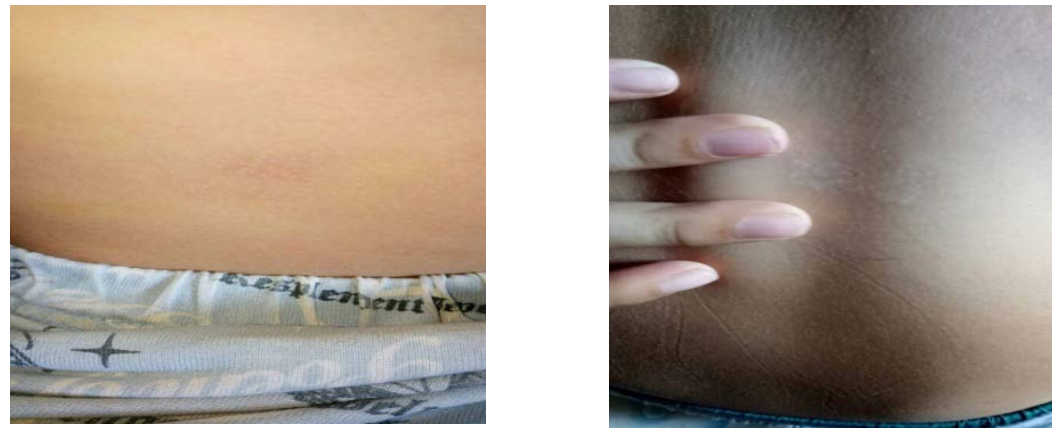

Gambar 2. Hari ke-14 Perbaikan optimal, kulit kembali normal

Pada pemeriksaan fisik didapatkan vesikel multipel bergerombol berisi cairan jernih di atas dasar kulit yang eritema yang terdapat di regio torakolumbal anterior dan posterior (T10 dan L2).

Pada anak yang imunokompeten, nyeri prodormal jarang terjadi, namun bila terjadi akan timbul nyeri beberapa hari sebelum timbul erupsi kulit. ${ }^{1,10,11}$ Gejala prodormal lainnya seperti demam dan malaise dapat berlangsung selama 7-10 hari. ${ }^{12}$ Selanjutnya vesikel akan pecah menjadi krusta dalam 1-2 minggu. ${ }^{1}$ Pada anak, infeksi herpes zoster biasanya lebih ringan dan proses penyembuhan terjadi dengan cepat dalam beberapa hari sampai 1 minggu. ${ }^{1}$ Distribusi herpes zoster biasanya segmental unilateral, dapat mengenai satu atau lebih dermatom, tetapi umumnya kurang dari dua dermatom yang berdekatan. ${ }^{13}$ Pada anak, dermatom yang paling sering terkena ialah pada daerah persarafan servikal dan sakral, sedangkan pada dewasa lebih sering ditemukan pada persarafan torakal dan lumbar.

Pemeriksaan penunjang tes Tzanck yang dilakukan pada pasien ini memperlihatkan sel-sel raksasa berinti banyak.
Pemeriksaan penunjang pada herpes zoster sama dengan pada varisela yaitu kultur virus, identifikasi virus melalui polymerase chain reaction (PCR), dan pemeriksaan serologis dengan fluorecent-antibody terhadap antigen membran VZV. Untuk jenis pemeriksaan yang lebih sederhana dapat dilakukan tes Tzanck pada vesikel baru yang dipecahkan. Hasil dinilai positif jika ditemukan sel raksasa berinti banyak. ${ }^{1,9}$

Penatalaksanaan spesifik yang diberikan pada pasien ini berupa asiklovir $4 \mathrm{x}$ $225 \mathrm{mg}$ selama 7 hari. Herpes zoster pada anak bersifat ringan sehingga dapat sembuh dengan sendirinya, maka penatalaksanaannya berupa terapi suportif., ${ }^{8}$ Begitu pula pada individu sehat dengan usia $<50$ tahun, penggunaan anti virus dianggap tidak diperlukan, karena risiko neuralgia pasca herpetika (NPH) lebih rendah. ${ }^{3}$ Pada pasien ini tujuan pemberian antiviral ialah untuk mengurangi komplikasi yang mungkin timbul, mengurangi nyeri prodormal yang dialami, menurunkan viral shedding, dan mempercepat penyembuhan lesi kulit. Penatalaksanaan lainnya yang diberikan pada pasien ini ialah parasetamol 3x375 mg. Berdasarkan acuan pustaka, untuk 
mengatasi nyeri ringan pada herpes zoster dapat diberikan parasetamol atau obat anti inflamasi non steroid. ${ }^{14}$

Komplikasi pada anak yang paling sering ialah infeksi sekunder dari bakteri, depigmentasi dan pembentukan jaringan parut sedangkan neuralgia paska herpetika (NPH) merupakan komplikasi yang jarang pada anak tetapi sering pada orang tua. ${ }^{8}$

Pada pasien ini prognosis quo ad vitam, quo ad functionam, quo ad sanationam ad bonam. Prognosis herpes zoster pada anak yang imunokompeten tergolong baik. $^{12}$ Hal ini disebabkan infeksi herpes zoster pada anak cenderung lebih ringan. ${ }^{1}$

\section{DAFTAR PUSTAKA}

1. Paller AS, Mancini AJ. Hurwitz Clinical Pediatric Dermatology (5th ed). Canada: Elsevier Saunders, 2016.

2. Mancini AJ, Wargon O. Viral infections. In: Schachner LA, Hansen RC. Pediatric Dermatology (4th ed). Philadelphia: Elsevier, 2011; p. 1425-69.

3. Schmader KE, Oxman MN. Varicella and herpes zoster. In: Goldsmith A, Katz SI, Gilchnest BA, Paller AS, Leffel DJ, Wolff K, editors. Fitzpatrick's Dermatology in General Medicine (8th ed). New York: Mc Graw-Hill, 2012; p. 2383-401.

4. Malik LM, Azfar NA, Khan AR, Hussain I, Jahangir M. Herpes zoster in children. JPAD. 2013;23(3):2267-71.

5. Mendoza N, Madkan V, Sia K, Willison B, Morrilo LK, Tyring SK. Human Herpes viruses. In: Bolognia JL, Jorizzo JL, Schaffer JV. Dermatology (3rd ed). Philadelphia: Elsevier, 2012; p. 1321-44.

6. Chen N, Li Q, Yang J, Zhou M, Zhou D, He L. Antiviral treatment for preventing nerve pain after shingles (postherpetic neuralgia). Cohrane Database Syst Rev. 2014;2;1-45

7. Tom WL, Freidlander SF. Viral exanthem. In: Irvine $\mathrm{AD}$, Hoeger $\mathrm{PH}$, Yan AC. Harpers' Textbook of Pediatric Dermatology (3rd ed). Oxford: Blackwell publishing, 2011; p. 49.1-14.

8. Pusponegoro EHD, Nilasari H, Lumintang H, Niode JN, Daili SF, Djauzi S. Buku Panduan Herpes Zoster di Indonesia 2014. Jakarta: Balai Penerbit FKUI, 2014.

9. May Kane KS, Lio PA, Stratigos AJ, Johnson RA. Color Atlas \& Synopsis of Pediatric Dermatology (2nd ed) . United States: McGraw-Hill, 2009.

10. Diana IA. Etiopatogenesis serta penatalaksanaan varisela dan herpes zoster pada bayi dan anak. In: Amiruddin MD, Djawad K, Ilyas FS, Tabri F, Batubara $\mathrm{DE}$, Hatta TH, et al, editors. Iktiosis, Infeksi Bakteri dan Virus pada Kulit Bayi dan Anak. Jakarta: Balai Penerbit FKUI, 2010; p. 74-87

11. Myers MG, Seward JF, LaRussa PS. Varicella-zoster virus. In: Kliegman RM, Behrman RE, Jenson HB, Stanton BF, editors. Nelson Textbook of Pediatrics (18th ed). Philadelphia: Elsevier Saunders, 2007; p. 1366-72.

12. Mallory SB, Bree A, Chern P. Illustrated Manual of Pediatric Dermatology Diagnosis and Management. United Kingdom: Taylor \& Francis, 2005.

13. Leung AK, Barankin B. Herpes zoster in childhood. OJPed. 2015;5:39-44

14. Perhimpunan Dokter Spesialis Kulit dan Kelamin Indonesia. Panduan Praktik Klinis Bagi Dokter Spesialis Kulit Dan Kelamin di Indonesia. Jakarta: Perhimpunan Dokter Spesialis Kulit dan Kelamin Indonesia (PERDOSKI), 2017. 